\title{
Biomarkers associated with binaprofen-induced liver injury
}

\author{
QIUPING GUO $^{1 *}$, JIANMIN GUO ${ }^{2-4 *}$, GUIYING CHEN ${ }^{1}$, ZHONG HAN $^{2,5}$, \\ BAIQUAN XIAO ${ }^{2,4}$, RUOMIN JIN ${ }^{5}$, CHUN LIANG $^{3}$ and WEI YANG ${ }^{2-4}$
}

\author{
${ }^{1}$ Drug Non-Clinical Evaluation and Research Center of Guangzhou General Pharmaceutical Research Institute, \\ Guangzhou, Guangdong 510240; ${ }^{2}$ Guangdong Key Laboratory of Animal Conservation and Resource Utilization, \\ Guangdong Public Laboratory of Wild Animal Conservation and Utilization, Guangdong Institute of \\ Applied Biological Resources, Guangzhou, Guangdong 510990; ${ }^{3}$ Division of Life Science, \\ Center for Cancer Research, State Key Lab for Molecular Neural Science, Bioengineering Graduate Program, \\ Hong Kong University of Science and Technology, Hong Kong, SAR 999077; ${ }^{4}$ Guangdong Lewwin Pharmaceutical Research \\ Institute Co., Ltd., Guangzhou, Guangdong 510000; ${ }^{5}$ Drug Safety Evaluation Center of Shanghai University of \\ Traditional Chinese Medicine, Shanghai 201203, P.R. China
}

Received November 18, 2017; Accepted August 14, 2018

DOI: $10.3892 / \mathrm{mmr} .2018 .9549$

\begin{abstract}
Drug-induced liver injury (DILI) is a common hepatic disease. The identification of biomarkers for DILI prediction is critical for rational drug use. The aim of the present study was to investigate liver injury caused by binaprofen and identify proteins that may serve as early biomarkers to predict DILI. For in vivo DILI assays, zebrafish were exposed to acetaminophen (APAP) and binaprofen for 12-96 h before lethal concentration $50\left(\mathrm{LC}_{50}\right)$, histopathological analysis, conventional and non-conventional biomarker measurements were conducted. In vitro assays were performed in cultured liver cells; after 6-24 h treatment with APAP and binaprofen the same measurements were conducted as aforementioned. The in vivo assays indicated that the $\mathrm{LC}_{50}$ of APAP was $5.2 \mathrm{mM}$, whereas the $\mathrm{LC}_{50}$ of binaprofen was $1.2 \mathrm{mM}$; 12-48 h post-treatment, liver cells exhibited mild to moderate vacuolization in a time- and concentration-dependent manner in response to both drugs. During this time, conventional and non-conventional biomarkers were also altered in a time- and concentration-dependent manner; however, alterations in the levels of non-conventional biomarkers occurred at an earlier time point compared with conventional biomarkers. The in vitro assays indicated that the half maximal inhibitory concentration $\left(\mathrm{IC}_{50}\right)$ of APAP was $16.2 \mathrm{mM}$, whereas the $\mathrm{IC}_{50}$
\end{abstract}

Correspondence to: Professor Wei Yang, Guangdong Key Laboratory of Animal Conservation and Resource Utilization, Guangdong Public Laboratory of Wild Animal Conservation and Utilization, Guangdong Institute of Applied Biological Resources, 105 Xingang Xi Road, Guangzhou, Guangdong 510990, P.R. China E-mail: docweiyang@163.com

*Contributed equally

Key words: binaprofen, liver injury, biomarkers of binaprofen was $5.3 \mathrm{mM} ; 12-48 \mathrm{~h}$ post-treatment, cultured liver cells exhibited mild to moderate swelling in a time- and concentration-dependent manner. Alterations in the levels of conventional and non-conventional biomarkers were similar to those observed in the in vivo assays. As a non-steroidal anti-inflammatory drug, binaprofen exhibited expected levels of liver toxicity in in vitro and in vivo assays, which were similar to APAP. Total bile acid and argininosuccinate lyase were identified as early biomarkers, which could accurately predict onset of binaprofen-induced liver injury.

\section{Introduction}

Drug-induced liver injury (DILI) is a common adverse reaction caused by numerous drugs (1-3), and being able to effectively predict and prevent DILI is a major focus of pharmacological research. Non-steroidal anti-inflammatory drugs (NSAIDs) are widely used to relieve pain and reduce inflammation (4-5), and each year, $>150$ million (6) prescriptions are generated in the United States of America for the management of acute and chronic pain, or rheumatic diseases. However, NSAIDs can cause several types of adverse reaction $(7,8)$; a study investigating the incidence of liver disease in patients demonstrated that the incidence of liver disease is 27 times higher in those using NSAIDs than those who do not (9). There are $>20$ types of NSAIDs currently in use, including aspirin, naproxen, ibuprofen, felbinac, ketoprofen, flurbiprofen, ketorolac, diclofenac, mefenamic acid and nimesulide, all of which have been reported to cause liver toxicity $(10,11)$. Therefore, it is necessary to develop novel methods to detect and prevent DILI caused by NSAIDs. Acetaminophen (APAP) is a common medication that has been extensively studied, with ample literature detailing its side effects and toxicity, particularly hepatotoxicity (12). In a recent study, it was confirmed that APAP exerts liver toxicity on zebrafish and liver cells (13). In the present study, APAP was used as a standard against which the side effects and toxicity of binaprofen were compared; binaprofen is currently being developed as an NSAID. 
In clinical medicine, a biomarker refers to a reliable and measurable indicator that can be used to gauge the severity or presence of a disease state; for example a naturally occurring molecule or gene. Some serum biomarkers have proven to be reliable tools for diagnosis, therapeutic decision-making and prognosis in many disease states. There are several biomarkers that are known to be important indicators of liver injury, and recently, liver biomarkers have been identified that may be used to predict liver tumors (14).

Binaprofen $\left(\mathrm{C}_{18} \mathrm{H}_{23} \mathrm{NO}_{5}\right)$ is a drug, currently not in clinical use, which has been referred to as felbinac trometamol in previous studies (15-17). Binaprofen is classified as an NSAID, which exerts anti-inflammatory, antipyretic and strong analgesic effects (15-17). In the present study, binaprofen-induced liver injury was investigated in vivo using a zebrafish model and in vitro using a human liver cell line.

\section{Materials and methods}

\section{In vivo analyses}

Zebrafish husbandry and treatment. Male and female AB-line adult zebrafish (Danio rerio) were obtained from the Southern Medical University (Guangzhou, China). Zebrafish were acclimated for 2 weeks prior to experimentation. Fish were maintained in aerated water at $23 \pm 1^{\circ} \mathrm{C}, 7.8 \pm 1 \mathrm{pH}$ and $0.25 \mathrm{~g} \mathrm{x} \mathrm{l}^{-1} \mathrm{CaCO}_{3}$ hardness, under a 12-h light/dark cycle. Animals were fed ad libitum. Experiments were performed using a total of 600 healthy fish aged 4-5 months.

Following the 2-week acclimation period, the fish were randomly allocated into experimental group tanks at a density of 1 fish/l of water. To obtain the lethal concentration $50\left(\mathrm{LC}_{50}\right)$, fish were treated with $1,2,4,8$ and $16 \mathrm{mM}$ APAP, and $0.40,0.60,0.90,1.35$ and $2.02 \mathrm{mM}$ binaprofen. To measure biomarkers, fish were treated with $4 \mathrm{mM}$ APAP and 0.40 and $0.80 \mathrm{mM}$ binaprofen. The drugs were added directly into the water at the appropriate concentrations; the tank water was changed daily and drugs were replenished following every change. Non-treated fish were used as a control group and tank water was also changed daily. Following 48-96 h of exposure to the drugs, all fish were euthanized by hypothermal shock (18).

The present study was approved by the Institutional Animal Care and Use Committee of Guangzhou Pharmaceutical Research Institute (protocol no. 2012005-01; Guangzhou, China) and the experiments were conducted in accordance with international guidelines for the care and use of laboratory animals.

Determination of $L C_{50}$. The appearance, behavior and food consumption of zebrafish was closely monitored during drug exposure. Rate of mortality was measured following $96 \mathrm{~h}$ of drug exposure ( $\mathrm{n}=20$ /group) and $\mathrm{LC}_{50}$ was calculated using probit graphical analysis (19).

Histological analysis of liver tissue. Zebrafish that were alive after $48 \mathrm{~h}$ of drug exposure were sacrificed to obtain liver tissues. Liver tissues were fixed in $10 \%$ formalin for $96 \mathrm{~h}$ at room temperature, embedded in paraffin wax, cut into $5 \mu \mathrm{m}$ sections and stained with $0.25 \%$ hematoxylin and $0.33 \%$ eosin (H\&E) for $1 \mathrm{~h}$ at room temperature. Liver cell morphology was examined under a microscope (BX51; Olympus Corporation, Tokyo, Japan). The sections were also examined for signs of pathology and graded using a semi-quantitative method. The grading system for liver cell pathology was as follows: i) Normal liver cells with an intact structure: '-', grade 0; ii) few small vacuoles found in the cytoplasm of liver cells indicating mild vacuolization: '+', grade 1; iii) large vacuoles found in the cytoplasm of liver cells with the cytoplasm compressed to one side indicating moderate vacuolization: '++', grade 2; iv) fused liver cells with different sized vesicles indicating severe vacuolization: ' +++ ', grade 3 and v) lysed liver cells lacking discernible nuclei indicating necrosis: '++++', grade 4.

Detection of serum biomarkers. Capillary blood was collected from tail cuttings after 12, 48 and $96 \mathrm{~h}$ of drug exposure ( $n=100 /$ group). Blood samples obtained from 20 fish were pooled together and centrifuged for $10 \mathrm{~min}$ at $1,800 \mathrm{x} \mathrm{g}$ at $4^{\circ} \mathrm{C}$. The resulting supernatant contained serum, which was collected for biomarker analysis. Conventional biomarkers that are widely used in clinical medicine for the diagnosis of liver disease include alanine transaminase (ALT), aspartate transaminase (AST), alkaline phosphatase (ALP) and lactate dehydrogenase ( $\mathrm{LDH})$; these markers were detected using a Hitachi 7100 biochemical analyzer (Hitachi, Ltd., Tokyo, Japan). Non-conventional biomarkers that have only recently been discovered or used for diagnosis of liver disease include total bile acid (TBA; cat. no. E003-2) purchased from Nanjing Jiancheng Bioengineering Institute (Nanjing, China). ELISA kits for arginase I (Arg-I; cat. no. CK-E11055H), argininosuccinate lyase (ASAL; cat. no. CK-E92131H), ornithine carbamyl transferase (OCT; cat. no. CK-E10835H), $\alpha$-glutathione S-transferase ( $\alpha$-GST; cat. no. CK-E10967H), prealbumin (PA; cat. no. CK-E11445H), xanthine oxidase (XOD; cat. no. CK-E92132H), isocitrate dehydrogenase (ICD; cat. no. CK-E10966H) and succinate dehydrogenase (SDH; cat. no. CK-E10965H) were from Dalian Fanbang Bio-Technology Co., Ltd. (Dalian, China). An ELX800 microplate reader (BioTek Instruments, Inc., Winooski, VT, USA), was used for detection according to the manufacturer's protocols.

\section{In vitro analyses}

Cell culture and treatment. L-02 liver cells (donated by Professor Chun Liang of the Division of Life Science, Center for Cancer Research, State Key Lab for Molecular Neural Science, Bioengineering Graduate Program, Hong Kong University of Science and Technology's and obtained from the Type Culture Collection of the Chinese Academy of Sciences, Shanghai, China) were cultured to a density of $1 \times 10^{5}$ cells $/ \mathrm{cm}^{2}$ in Williams' medium E (WME; Sigma-Aldrich; Merck KGaA, Darmstadt, Germany) supplemented with $10 \%$ fetal bovine serum(FBS; Merck KGaA), 10 U/1 insulin-transferrin-selenium (Sigma-Aldrich; Merck KGaA), $10 \mathrm{U} / 1$ dexamethasone (Merck KGaA), 40x10 $0^{6} \mathrm{U} / 1$ penicillin and $0.1 \mathrm{~g} / 1$ streptomycin (Baiyunshan Pharmaceutical Co., Ltd., Guangzhou, China) at $37^{\circ} \mathrm{C}$ in a humidified atmosphere containing $5 \% \mathrm{CO}_{2}$.

To determine half maximal inhibitory concentration $\left(\mathrm{IC}_{50}\right)$, liver cell cultures were treated with $1,2,4,8,16$ and $32 \mathrm{mM}$ APAP or $0.8,1.9,4.8,12$ and $30 \mathrm{mM}$ binaprofen. Prior to 
biomarker measurement, cells were treated with $8 \mathrm{mM}$ APAP or 0.8 and $4.8 \mathrm{mM}$ binaprofen. The drugs were added directly into media at the appropriate concentrations. The media were changed daily and the drugs were replenished following each change. Non-treated liver cells were used as a control. $\mathrm{IC}_{50}$ values and biomarkers were measured after 6,12 and $24 \mathrm{~h}$ of drug exposure.

Determination of $I_{50}$. The $\mathrm{IC}_{50}$ of the control, APAP-treated and binaprofen-treated cells were measured using MTT assays. Briefly, $100 \mu 1$ MTT solution in WME supplemented with $10 \%$ FBS was added to the cells, which were incubated for $4 \mathrm{~h}$ at $4^{\circ} \mathrm{C}$. Subsequently, cells were transferred to $150 \mu$ l dimethyl sulfoxide and incubated for $10 \mathrm{~min}$ with constant agitation. Readings were taken at 630 and $490 \mathrm{~nm}$, using an ELX800 microplate reader (BioTek Instruments, Inc.). The percentage inhibition and $\mathrm{IC}_{50}$ were determined using the curve-fitting method (20). The percentage inhibition was calculated using the following formula: [(D490 drug - D630 drug $) /\left(\right.$ D490 control $^{-D 630}$ control $\left.)\right]$ x100\%.

Histological analysis of the liver cell line. Following $24 \mathrm{~h}$ drug exposure, the cells were cultured in RPMI1640 medium (including $10 \% \mathrm{FBS}$ ) at $37^{\circ} \mathrm{C}$ in $5 \% \mathrm{CO}_{2}$, and grew for $24 \mathrm{~h}$ before being washed twice with PBS and fixed in $4 \%$ paraformaldehyde at room temperature for $96 \mathrm{~h}$. The cells were stained with H\&E, and liver cell morphology was examined under a light microscope (BX51; Olympus Corporation). The sections were examined for signs of pathology using a semi-quantitative method; the grading system for cellular pathology was as follows: i) Normal intact cells: '-', grade 0; ii) enlarged round cells with normal cytoplasmic arrangement indicating mild swelling: '+', grade 1; iii) large round cells with slight cytoplasmic staining exhibiting normal cytoplasmic arrangement indicating moderate swelling: '++', grade 2; iv) very large round cells with many vacuoles and a disordered cytoplasm indicating rupture and severe swelling: ' +++ ', grade 3 and v) lysed cells with no visible nuclei indicating necrosis: '++++', grade 4.

Biomarker detection. Media were collected from the cells and conventional biomarkers (ALT, AST, ALP, and LDH) were detected using a Hitachi 7100 biochemical analyzer (Hitachi, Ltd.), whereas non-conventional biomarkers (TBA and ASAL) were detected using ELISA kits (Dalian Fanbang Chemical Technology Development Co., Ltd.), according to the manufacturer's protocol.

Statistical analysis. Quantitative values are presented as the means \pm standard deviation of three experimental repeats, and were checked for normality and equal variance. Normally distributed data were analyzed using Student's t-test, or one-way analysis of variance followed by Tukey's post hoc analysis. Non-normally distributed data were analyzed using one-way analysis of variance followed by Kruskal-Wallis test. Analysis of liver cell morphology was conducted using the Ridit assay. $\mathrm{P}<0.05$ was considered to indicate a statistically significant difference. All analyses were carried out using SPSS software (version 13.0; SPSS, Inc., Chicago, IL, USA). Receiver operating characteristic (ROC) curve was used to determine the sensitivity of a biomarker to accurately predict
DILI. ROC curves were generated using MedCalc software (version 11.4.2.0; MedCalc Software bvba, Ostend, Belgium).

\section{Results}

In vivo analyses

Determining $L C_{50}$ in an in vivo model of DILI. In the present study, the results indicated that treatment with $>2 \mathrm{mM}$ APAP had obvious toxic effects on zebrafish; causing impaired swimming and abnormal swimming position. The $\mathrm{LC}_{50}$ for APAP was calculated to be $5.2 \mathrm{mM}$ with a $95 \%$ confidence interval (CI) of 4.6-7.2 mM. Treatment with $>0.40 \mathrm{mM}$ binaprofen also caused obvious toxic effects. The $\mathrm{LC}_{50}$ of binaprofen was calculated to be $1.2 \mathrm{mM}$ with a $95 \% \mathrm{CI}$ of $1.1-1.3 \mathrm{mM}$ (data not shown).

Histological analysis. Treatment with $4 \mathrm{mM}$ APAP caused $10 \%$ mortality of zebrafish after $48 \mathrm{~h}$ exposure to the drug. Treatment with $0.40 \mathrm{mM}$ binaprofen had no impact on mortality in zebrafish even following $48 \mathrm{~h}$ of exposure; however, increasing the concentration to $0.80 \mathrm{mM}$ binaprofen led to $10 \%$ mortality of zebrafish after $48 \mathrm{~h}$ of exposure. At 12 or $24 \mathrm{~h}$ post-drug treatment, the rate of mortality was equal or lower compared with at $48 \mathrm{~h}$.

Compared with the control group, $4 \mathrm{mM}$ APAP treatment for 12 and $24 \mathrm{~h}$ resulted in mild vacuolization (+) in 2/10 liver tissues; however, following $48 \mathrm{~h}$ of treatment all liver tissues $(10 / 10)$ had mild or moderate vacuolization $(+/++; \mathrm{P}<0.05)$. Treatment with $0.40 \mathrm{mM}$ binaprofen for $48 \mathrm{~h}$ resulted in no damage in liver tissues; however, treatment with $0.80 \mathrm{mM}$ resulted in mild vacuolization $(+)$ in $1 / 10$ liver tissues after $12 \mathrm{~h}$, mild vacuolization (+) in 2/10 liver tissues after $24 \mathrm{~h}$ and mild or moderate vacuolization $(+/++)$ in $5 / 10$ liver tissues $(\mathrm{P}<0.05)$ after $48 \mathrm{~h}$ of treatment (Table I and Fig. 1).

Detection of serum biomarkers. Compared with in the control group, 4 mM APAP treatment caused an increase in ALT levels at 24 and $48 \mathrm{~h}$, an increase in LDH levels at $48 \mathrm{~h}$, a decrease in Arg-I levels at 12 and $24 \mathrm{~h}$, and an increase in ASAL levels at 12,24 and 48 h post-drug exposure. The levels of $\alpha$-GST were decreased at $24 \mathrm{~h}$, OCT levels increased at $48 \mathrm{~h}$, TBA levels were increased at 12, 24 and $48 \mathrm{~h}$, PA levels were increased at $48 \mathrm{~h}$, XOD levels were increased at 24 and $48 \mathrm{~h}$, and ICD levels were increased at $12 \mathrm{~h}$ post-drug exposure (Table II).

Treatment with $0.4 \mathrm{mM}$ binaprofen resulted in a decrease in LDH levels at $24 \mathrm{~h}$, a decrease in Arg-I levels at 12 and $24 \mathrm{~h}$, an increase in ASAL levels at 12, 24 and $48 \mathrm{~h}$, an increase in OCT levels at $48 \mathrm{~h}$, and an increase in TBA levels at 24 and $48 \mathrm{~h}$ post-drug exposure. Treatment with $0.8 \mathrm{mM}$ binaprofen resulted in an increase in ALT levels at $48 \mathrm{~h}$, an increase in AST levels at $48 \mathrm{~h}$, an increase in LDH levels at $48 \mathrm{~h}$, a decrease in Arg-I levels at 12, 24 and $48 \mathrm{~h}$, an increase in ASAL levels at 12, 24 and $48 \mathrm{~h}$, a decrease in $\alpha$-GST levels at $12 \mathrm{~h}$, an increase in TBA levels at 12, 24 and $48 \mathrm{~h}$, an increase in PA levels at $48 \mathrm{~h}$, an increase in XOD levels at 24 and $48 \mathrm{~h}$, and a decrease in ICD levels at $24 \mathrm{~h}$ post-drug exposure (Table II).

Overall, ALT, LDH, ASAL, TBA and PA levels in response to binaprofen were altered in a concentration- and time-dependent manner. 
Table I. Histopathological scoring of liver sections from APAP- and binaprofen-treated zebrafish.

\begin{tabular}{|c|c|c|c|c|c|c|}
\hline \multirow[b]{2}{*}{ Group } & \multirow[b]{2}{*}{ Concentration (mM) } & \multirow[b]{2}{*}{$\mathrm{n}$} & \multirow[b]{2}{*}{ Pathological score } & \multicolumn{3}{|c|}{ Time } \\
\hline & & & & $12 \mathrm{~h}$ & $24 \mathrm{~h}$ & $48 \mathrm{~h}$ \\
\hline \multirow[t]{5}{*}{ Control } & - & 10 & - & 10 & 10 & 10 \\
\hline & & & + & 0 & 0 & 0 \\
\hline & & & ++ & 0 & 0 & 0 \\
\hline & & & +++ & 0 & 0 & 0 \\
\hline & & & ++++ & 0 & 0 & 0 \\
\hline \multirow[t]{5}{*}{ APAP } & 4 & 10 & - & 8 & 8 & $0^{\mathrm{a}}$ \\
\hline & & & + & 2 & 2 & 6 \\
\hline & & & ++ & 0 & 0 & 4 \\
\hline & & & +++ & 0 & 0 & 0 \\
\hline & & & ++++ & 0 & 0 & 0 \\
\hline \multirow[t]{5}{*}{ Binaprofen } & 0.4 & 10 & - & 10 & 10 & 9 \\
\hline & & & + & 0 & 0 & 1 \\
\hline & & & ++ & 0 & 0 & 0 \\
\hline & & & +++ & 0 & 0 & 0 \\
\hline & & & ++++ & 0 & 0 & 0 \\
\hline \multirow[t]{5}{*}{ Binaprofen } & 0.8 & 10 & - & 9 & 8 & $5^{\mathrm{a}}$ \\
\hline & & & + & 1 & 2 & 3 \\
\hline & & & ++ & 0 & 0 & 2 \\
\hline & & & +++ & 0 & 0 & 0 \\
\hline & & & ++++ & 0 & 0 & 0 \\
\hline
\end{tabular}

Analysis of liver cell morphology was conducted using the Ridit assay. ${ }^{a} \mathrm{P}<0.05$ vs. the control group. APAP, acetaminophen.
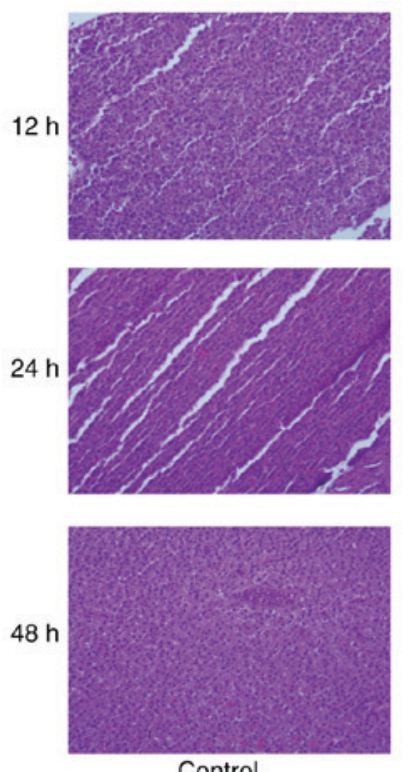

Control
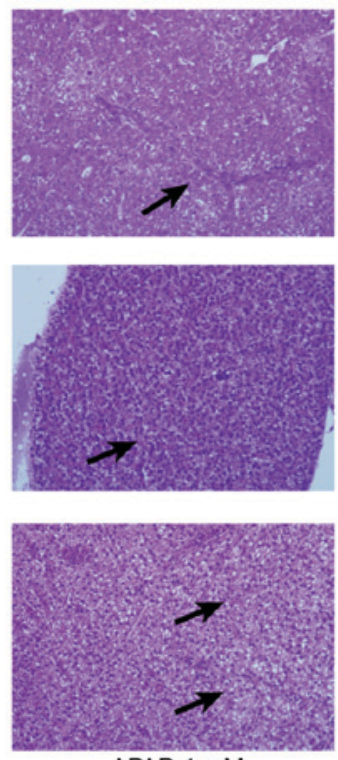

APAP $4 \mathrm{mM}$
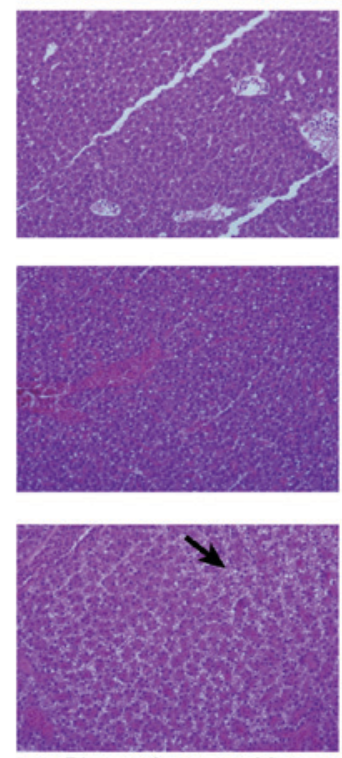

Binaprofen $0.4 \mathrm{mM}$
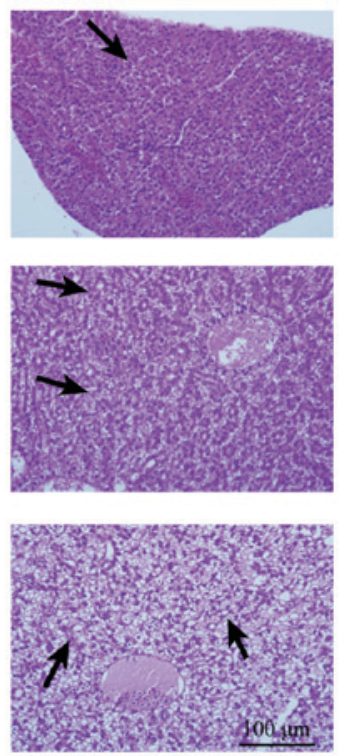

Binaprofen $0.8 \mathrm{mM}$

Figure 1. Hematoxylin and eosin staining of liver sections from APAP- and binaprofen-treated zebrafish. Treatment with 4 mM APAP resulted in mild to moderate vacuolization in 2/10,2/10 and 10/10 liver tissues at 12, 24 and $48 \mathrm{~h}$, respectively. Treatment with 0.4 mM binaprofen caused mild vacuolization in $1 / 10$ liver tissues at $48 \mathrm{~h}$, whereas $0.8 \mathrm{mM}$ binaprofen resulted in mild to moderate vacuolization in $1 / 10,2 / 10$ and $5 / 10$ liver tissues at 12,24 and $48 \mathrm{~h}$, respectively. Arrows indicate abnormal cells. Magnification, x400. APAP, acetaminophen.

ROC curve analysis. Alterations in ASAL and TBA levels were most sensitive at predicting DILI following $12 \mathrm{~h}$ binaprofen exposure compared with in the control group. The sensitivity of the biomarkers at $12 \mathrm{~h}$ was ranked as follows: TBA $>$ ASAL $>$ ALT $>$ LDH $>$ AST. Following $24 \mathrm{~h}$ of drug exposure, ASAL, TBA and ALT were identified to be the most 
Table II. Serum biomarker detection (U/1) of APAP- and binaprofen-treated zebrafish.

\begin{tabular}{|c|c|c|c|c|c|c|}
\hline \multirow[b]{2}{*}{ Biomarker } & \multirow[b]{2}{*}{ Group } & \multirow[b]{2}{*}{ Concentration (mM) } & \multirow[b]{2}{*}{$\mathrm{n}$} & \multicolumn{3}{|c|}{ Time } \\
\hline & & & & $12 \mathrm{~h}$ & $24 \mathrm{~h}$ & $48 \mathrm{~h}$ \\
\hline \multirow[t]{4}{*}{ ALT } & Control & - & 5 & $9.2 \pm 4.9$ & $9.0 \pm 5.5$ & $9.6 \pm 7.2$ \\
\hline & APAP & 4 & 5 & $11.0 \pm 5.1$ & $18.2 \pm 2.7^{\mathrm{a}}$ & $54.4 \pm 31.1^{\mathrm{a}}$ \\
\hline & Binaprofen & 0.4 & 5 & $5.8 \pm 1.7$ & $8.5 \pm 0.6$ & $22.3 \pm 10.9^{\mathrm{a}}$ \\
\hline & Binaprofen & 0.8 & 5 & $10.5 \pm 0.6$ & $26.8 \pm 17.6^{\mathrm{a}}$ & $60.3 \pm 9.7^{b}$ \\
\hline \multirow[t]{4}{*}{$\mathrm{AST}$} & Control & - & 5 & $1,145.2 \pm 522.6$ & $1,101.2 \pm 304.0$ & $1,043.6 \pm 399.2$ \\
\hline & APAP4 & 4 & 5 & $1,365.0 \pm 774.0$ & $1,296.0 \pm 267.9$ & $1,605.4 \pm 655.7$ \\
\hline & Binaprofen & 0.4 & 5 & $896.5 \pm 77.5$ & $719.8 \pm 99.2$ & $1,359.5 \pm 279.3$ \\
\hline & Binaprofen & 0.8 & 5 & $1,074.8 \pm 328.3$ & $1,587.8 \pm 453.9$ & $2,172.5 \pm 37.9^{\mathrm{a}}$ \\
\hline \multirow[t]{4}{*}{ ALP } & Control & - & 5 & $0.00 \pm 0.00$ & $0.00 \pm 0.00$ & $0.60 \pm 0.89$ \\
\hline & APAP & 4 & 5 & $0.00 \pm 0.00$ & $0.00 \pm 0.00$ & $5.20 \pm 7.16$ \\
\hline & Binaprofen & 0.4 & 5 & $0.50 \pm 0.57^{\mathrm{a}}$ & $0.00 \pm 0.00$ & $2.25 \pm 4.50$ \\
\hline & Binaprofen & 0.8 & 5 & $0.00 \pm 0.00$ & $0.00 \pm 0.00$ & $0.00 \pm 0.00$ \\
\hline \multirow[t]{4}{*}{ LDH } & Control & - & 5 & $1,478.2 \pm 901.9$ & $1,457.4 \pm 574.3$ & $706.2 \pm 209.5$ \\
\hline & APAP & 4 & 5 & $1,441.0 \pm 793.4$ & $1,251.0 \pm 591.7$ & $1,957.8 \pm 955.2^{\mathrm{a}}$ \\
\hline & Binaprofen & 0.4 & 5 & $890.3 \pm 193.7$ & $620.0 \pm 130.5^{\mathrm{a}}$ & $1,107.7 \pm 556.3$ \\
\hline & Binaprofen & 0.8 & 5 & $1,040.5 \pm 356.9$ & $1,350.5 \pm 612.9$ & $2,003.5 \pm 158.1^{b}$ \\
\hline \multirow[t]{4}{*}{ Arg-I (mg/l) } & Control & - & 5 & $13.1 \pm 0.6$ & $14.6 \pm 0.7$ & $12.6 \pm 0.3$ \\
\hline & APAP & 4 & 5 & $10.1 \pm 0.3^{b}$ & $12.6 \pm 0.1^{\mathrm{b}}$ & $12.1 \pm 0.4$ \\
\hline & Binaprofen & 0.4 & 5 & $11.7 \pm 0.6^{\mathrm{b}}$ & $11.7 \pm 0.6^{b}$ & $12.4 \pm 0.7$ \\
\hline & Binaprofen & 0.8 & 5 & $11.3 \pm 0.7^{b}$ & $11.4 \pm 0.4^{\mathrm{b}}$ & $11.3 \pm 0.5^{\mathrm{b}}$ \\
\hline \multirow[t]{4}{*}{ ASAL } & Control & - & 5 & $35.8 \pm 1.6$ & $43.7 \pm 1.1$ & $45.0 \pm 4.8$ \\
\hline & APAP & 4 & 5 & $53.6 \pm 4.7^{\mathrm{b}}$ & $59.1 \pm 5.1^{\mathrm{b}}$ & $69.1 \pm 0.9^{\mathrm{b}}$ \\
\hline & Binaprofen & 0.4 & 5 & $44.3 \pm 4.4^{\mathrm{b}}$ & $50.0 \pm 2.8^{\mathrm{b}}$ & $52.5 \pm 4.2^{\mathrm{b}}$ \\
\hline & Binaprofen & 0.8 & 5 & $44.5 \pm 6.0^{\mathrm{b}}$ & $54.1 \pm 8.3^{b}$ & $57.3 \pm 5.5^{\mathrm{b}}$ \\
\hline \multirow[t]{4}{*}{$\alpha-G S T(m g / l)$} & Control & - & 5 & $85.5 \pm 4.4$ & $91.9 \pm 7.1$ & $96.7 \pm 6.7$ \\
\hline & APAP & 4 & 5 & $90.1 \pm 22.7$ & $82.8 \pm 4.5^{\mathrm{a}}$ & $92.3 \pm 24.1$ \\
\hline & Binaprofen & 0.4 & 5 & $91.9 \pm 9.3$ & $97.0 \pm 6.5$ & $93.7 \pm 5.2$ \\
\hline & Binaprofen & 0.8 & 5 & $73.7 \pm 4.3^{b}$ & $94.1 \pm 20.1$ & $85.3 \pm 19.1$ \\
\hline \multirow[t]{4}{*}{ OCT } & Control & - & 5 & $8.9 \pm 0.5$ & $9.9 \pm 1.2$ & $8.7 \pm 0.1$ \\
\hline & APAP & 4 & 5 & $8.8 \pm 0.5$ & $9.1 \pm 0.2$ & $10.2 \pm 1.2^{\mathrm{a}}$ \\
\hline & Binaprofen & 0.4 & 5 & $9.3 \pm 0.5$ & $9.6 \pm 0.7$ & $9.5 \pm 0.2^{b}$ \\
\hline & Binaprofen & 0.8 & 5 & $8.5 \pm 0.7$ & $8.5 \pm 0.6$ & $8.7 \pm 1.8$ \\
\hline \multirow[t]{4}{*}{$\mathrm{TBA}(\mu \mathrm{M} / \mathrm{l})$} & Control & - & 5 & $2.6 \pm 1.1$ & $3.2 \pm 0.3$ & $2.8 \pm 1.1$ \\
\hline & APAP & 4 & 5 & $6.6 \pm 2.1^{\mathrm{a}}$ & $7.6 \pm 1.3^{\mathrm{b}}$ & $10.1 \pm 0.3^{b}$ \\
\hline & Binaprofen & 0.4 & 5 & $3.6 \pm 1.8$ & $6.0 \pm 1.8^{\mathrm{a}}$ & $7.8 \pm 1.3^{\mathrm{b}}$ \\
\hline & Binaprofen & 0.8 & 5 & $5.5 \pm 1.9^{\mathrm{a}}$ & $6.0 \pm 2.2^{\mathrm{b}}$ & $8.3 \pm 1.5^{\mathrm{b}}$ \\
\hline \multirow[t]{4}{*}{$\mathrm{PA}(\mathrm{mg} / \mathrm{l})$} & Control & - & 5 & $44.33 \pm 18.38$ & $52.25 \pm 20.47$ & $56.00 \pm 22.83$ \\
\hline & APAP & 4 & 5 & $81.50 \pm 44.55$ & $95.83 \pm 38.52$ & $136.16 \pm 46.01^{\mathrm{a}}$ \\
\hline & Binaprofen & 0.4 & 5 & $51.16 \pm 21.23$ & $62.50 \pm 37.18$ & $86.50 \pm 30.78$ \\
\hline & Binaprofen & 0.8 & 5 & $52.50 \pm 16.69$ & $109.83 \pm 44.77$ & $122.83 \pm 39.62^{a}$ \\
\hline \multirow[t]{4}{*}{ XOD } & Control & - & 5 & $0.71 \pm 0.12$ & $0.68 \pm 0.17$ & $0.73 \pm 0.13$ \\
\hline & APAP & 4 & 5 & $0.67 \pm 0.29$ & $1.23 \pm 0.17^{\mathrm{a}}$ & $2.01 \pm 0.52^{\mathrm{b}}$ \\
\hline & Binaprofen & 0.4 & 5 & $0.77 \pm 0.15$ & $0.74 \pm 0.35$ & $0.67 \pm 0.29$ \\
\hline & Binaprofen & 0.8 & 5 & $0.76 \pm 0.53$ & $0.64 \pm 40$ & $1.28 \pm 0.32$ \\
\hline \multirow[t]{4}{*}{ ICD } & Control & - & 5 & $2.03 \pm 0.27$ & $2.32 \pm 0.45$ & $2.06 \pm 0.32$ \\
\hline & APAP & 4 & 5 & $2.66 \pm 0.28^{a}$ & $2.40 \pm 0.18$ & $2.26 \pm 0.54$ \\
\hline & Binaprofen & 0.4 & 5 & $2.22 \pm 0.50$ & $1.80 \pm 0.18$ & $1.88 \pm 0.15$ \\
\hline & Binaprofen & 0.8 & 5 & $2.23 \pm 0.50$ & $1.48 \pm 0.62^{\mathrm{a}}$ & $1.89 \pm 0.65$ \\
\hline
\end{tabular}


Table II. Continued.

\begin{tabular}{|c|c|c|c|c|c|c|}
\hline \multirow[b]{2}{*}{ Biomarker } & \multirow[b]{2}{*}{ Group } & \multirow[b]{2}{*}{ Concentration $(\mathrm{mM})$} & \multirow[b]{2}{*}{$\mathrm{n}$} & \multicolumn{3}{|c|}{ Time } \\
\hline & & & & $12 \mathrm{~h}$ & $24 \mathrm{~h}$ & $48 \mathrm{~h}$ \\
\hline \multirow[t]{4}{*}{ SDH } & Control & - & 5 & $1.02 \pm 0.39$ & $0.94 \pm 0.17$ & $1.03 \pm 0.34$ \\
\hline & APAP & 4 & 5 & $1.49 \pm 1.02$ & $1.03 \pm 0.56$ & $1.45 \pm 0.58$ \\
\hline & Binaprofen & 0.4 & 5 & $1.10 \pm 0.34$ & $1.51 \pm 0.90$ & $2.01 \pm 0.99$ \\
\hline & Binaprofen & 0.8 & 5 & $1.03 \pm 0.82$ & $1.83 \pm 0.91$ & $2.23 \pm 1.05$ \\
\hline
\end{tabular}

Data are presented as the means \pm standard deviation. Data were analyzed using one-way analysis of variance followed by Kruskal-Wallis test. ${ }^{a} \mathrm{P}<0.05,{ }^{b} \mathrm{P}<0.01$ vs. the control group. $\alpha$-GST, $\alpha$-glutathione S-transferase; ALT, alanine transaminase; ALP, alkaline phosphatase; APAP, acetaminophen; Arg-I, arginase I; ASAL, argininosuccinate lyase; AST, aspartate transaminase; ICD, isocitrate dehydrogenase; LDH, lactate dehydrogenase; OCT, ornithine carbamyl transferase; PA, prealbumin; SDH, succinate dehydrogenase; TBA, total bile acid; XOD, xanthine oxidase.

sensitive. The sensitivity of biomarkers at $24 \mathrm{~h}$ was ranked as follows: ALT $>$ TBA $>$ ASAL $>$ LDH $=$ AST. The biomarkers ASAL, TBA, ALT, AST and LDH were identified to be sensitive biomarkers at $48 \mathrm{~h}$; the relative ranking was as follows: TBA=ALT=AST $=$ LDH $>$ ASAL (Table III).

As shown in Table III, after $48 \mathrm{~h}$ of drug exposure the levels of non-conventional biomarkers (TBA and ASAL) and conventional biomarkers (ALT, AST and LDH) were significantly altered in line with DILI.

\section{In vitro analyses}

Determining $I C_{50}$ in an in vitro model of DILI. The results demonstrated that treatment of liver cell lines with $>8 \mathrm{mM}$ APAP significantly inhibited cell growth. The $\mathrm{IC}_{50}$ for APAP was calculated to be $16.2 \mathrm{mM}$ with a $95 \%$ CI of $11.4-21.2 \mathrm{mM}$. Treatment with $>4.8 \mathrm{mM}$ binaprofen also had a significant inhibitory effect on liver cells. The $\mathrm{IC}_{50}$ for binaprofen was calculated to be $5.3 \mathrm{mM}$ with a $95 \%$ CI of 4.5-6.2 $\mathrm{mM}$ (data not shown).

Histological analysis. The survival of cultured liver cells decreased in a time-dependent manner following treatment with $8 \mathrm{mM}$ APAP; the percentage of viable cells at different time points were as follows: $87.5 \%$ at $6 \mathrm{~h}, 65.3 \%$ at $12 \mathrm{~h}$ and $61.2 \%$ at $24 \mathrm{~h}$. The survival of cultured liver cells also decreased in a time-dependent manner with $0.8 \mathrm{mM}$ binaprofen treatment; the percentage of viable cells at the different time points were as follows: $98.5 \%$ at $6 \mathrm{~h}, 94.6 \%$ at $12 \mathrm{~h}$ and $91.0 \%$ at $24 \mathrm{~h}$. Increasing the concentration of binaprofen to $4.8 \mathrm{mM}$ resulted in the following percentages of viable cells at the various time points: $83.5 \%$ at $6 \mathrm{~h}, 63.7 \%$ at $12 \mathrm{~h}$ and $54.2 \%$ at $24 \mathrm{~h}$. The percentage of viable cells in the $0.8 \mathrm{mM}$ binaprofen-treated group was higher compared with in the $4.8 \mathrm{mM}$ binaprofen-treated group (data not shown).

Treatment with $8 \mathrm{mM}$ APAP caused 1/5 liver cell cultures to exhibit mild swelling (+) at 6 and $12 \mathrm{~h}$, and 5/5 liver cells to exhibit mild or moderate (+/++) swelling at $24 \mathrm{~h}$ post-drug exposure (Table IV; Fig. 2); however, $0.8 \mathrm{mM}$ binaprofen treatment resulted in no abnormalities in the liver cells at 6,12 or $24 \mathrm{~h}$ post-drug exposure. Treatment with $4.8 \mathrm{mM}$ binaprofen caused
Table III. Biomarker sensitivity analysis in zebrafish serum.

\begin{tabular}{llll}
\hline & \multicolumn{3}{c}{ Time } \\
\cline { 2 - 4 } Biomarker & $12 \mathrm{~h}$ & $24 \mathrm{~h}$ & $48 \mathrm{~h}$ \\
\hline ASAL & $0.81^{\mathrm{a}}$ & $0.80^{\mathrm{a}}$ & $0.90^{\mathrm{a}}$ \\
TBA & $0.93^{\mathrm{a}}$ & $1.00^{\mathrm{a}}$ & $1.00^{\mathrm{a}}$ \\
ALT & 0.75 & $0.93^{\mathrm{a}}$ & $1.00^{\mathrm{a}}$ \\
AST & 0.50 & 0.50 & $1.00^{\mathrm{a}}$ \\
LDH & 0.56 & 0.50 & $1.00^{\mathrm{a}}$
\end{tabular}

Receiver operating characteristic curve was used to determine the sensitivity of the analyzed biomarkers for the diagnosis of drug-induced liver injury, ${ }^{\mathrm{a}} \mathrm{P}<0.05$ vs. control group. ALT, alanine transaminase; ASAL, argininosuccinate lyase; AST, aspartate transaminase; $\mathrm{LDH}$, lactate dehydrogenase; TBA, total bile acid.

no liver cell abnormalities at $6 \mathrm{~h}$, although $1 / 5$ liver cell cultures exhibited mild swelling (+) at $12 \mathrm{~h}$ and $4 / 5$ liver cells exhibited mild to moderate swelling (+/++) $24 \mathrm{~h}$ post-drug exposure.

Detection of biomarkers. Treatment with $8 \mathrm{mM}$ APAP caused ALT and LDH levels to increase at $24 \mathrm{~h}$, ASAL levels to increase at 12 and $24 \mathrm{~h}$ and TBA levels to increase at 6,12 and 24 h post-drug exposure $(\mathrm{P}<0.05$; Table $\mathrm{V})$.

Treatment with $0.8 \mathrm{mM}$ binaprofen treatment caused $\mathrm{LDH}$ levels to increase at $24 \mathrm{~h}, \mathrm{ASAL}$ levels to increase at 6, 12 and $24 \mathrm{~h}$, and TBA levels to increase at 12 and $24 \mathrm{~h}$. At a concentration of $4.8 \mathrm{mM}$, binaprofen treatment caused ALT and AST levels to increase at $24 \mathrm{~h}, \mathrm{LDH}$ levels to increase at $24 \mathrm{~h}$, and ASAL and TBA levels to increase at 6, 12 and $24 \mathrm{~h}$ post-drug exposure $(\mathrm{P}<0.05$; Table $\mathrm{V})$.

The alterations in ALT, AST, LDH, ASAL and TBA levels in response to binaprofen occurred in a concentration- and time-dependent manner.

ROC curve analysis. Compared with in the control group, alterations in ASAL levels were most sensitive in predicting DILI following $6 \mathrm{~h}$ of binaprofen exposure; the sensitivity of the various biomarkers at $6 \mathrm{~h}$ was ranked as follows: 
Table IV. Histopathological scoring of APAP- and binaprofen-treated L-02 liver cell line cultures.

\begin{tabular}{|c|c|c|c|c|c|c|}
\hline \multirow[b]{2}{*}{ Group } & \multirow[b]{2}{*}{ Concentration (mM) } & \multirow[b]{2}{*}{$\mathrm{n}$} & \multirow[b]{2}{*}{ Pathological score } & \multicolumn{3}{|c|}{ Time } \\
\hline & & & & $6 \mathrm{~h}$ & $12 \mathrm{~h}$ & $24 \mathrm{~h}$ \\
\hline \multirow[t]{5}{*}{ Control } & - & 5 & - & 5 & 5 & 5 \\
\hline & & & + & 0 & 0 & 0 \\
\hline & & & ++ & 0 & 0 & 0 \\
\hline & & & +++ & 0 & 0 & 0 \\
\hline & & & ++++ & 0 & 0 & 0 \\
\hline \multirow[t]{5}{*}{ APAP } & 8 & 5 & - & 4 & 4 & $0^{\mathrm{a}}$ \\
\hline & & & + & 1 & 1 & 4 \\
\hline & & & ++ & 0 & 0 & 1 \\
\hline & & & +++ & 0 & 0 & 0 \\
\hline & & & ++++ & 0 & 0 & 0 \\
\hline \multirow[t]{5}{*}{ Binaprofen } & 0.8 & 5 & - & 5 & 5 & 5 \\
\hline & & & + & 0 & 0 & 0 \\
\hline & & & ++ & 0 & 0 & 0 \\
\hline & & & +++ & 0 & 0 & 0 \\
\hline & & & ++++ & 0 & 0 & 0 \\
\hline \multirow[t]{5}{*}{ Binaprofen } & 4.8 & 5 & - & 5 & 4 & $1^{\mathrm{a}}$ \\
\hline & & & + & 0 & 1 & 3 \\
\hline & & & ++ & 0 & 0 & 1 \\
\hline & & & +++ & 0 & 0 & 0 \\
\hline & & & ++++ & 0 & 0 & 0 \\
\hline
\end{tabular}

Analysis of liver cell morphology was conducted using the Ridit assay. ${ }^{\text {a }}<0.05$ vs. the control group. APAP, acetaminophen.
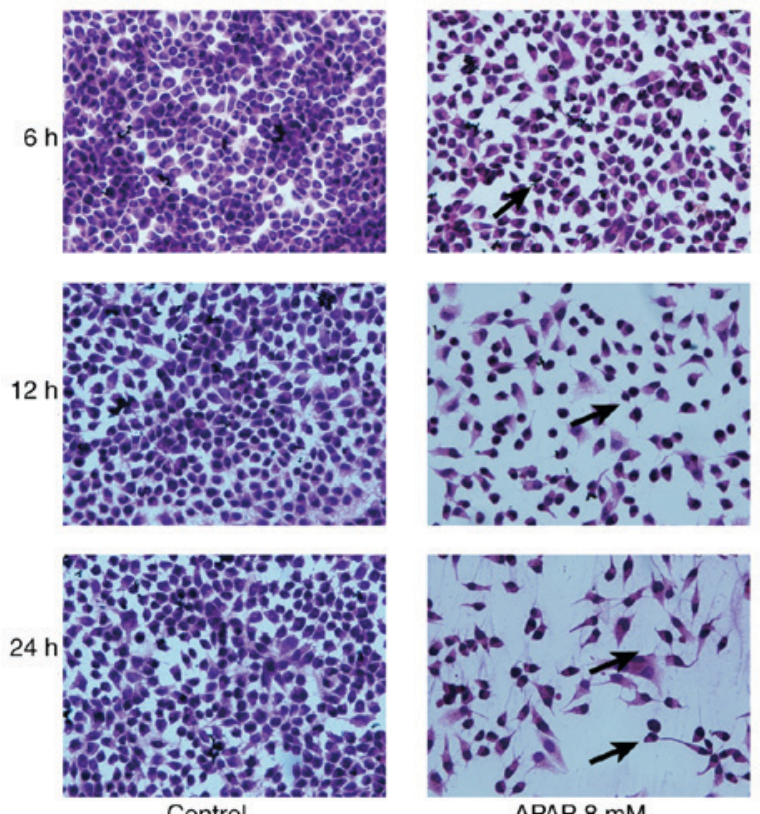

Control

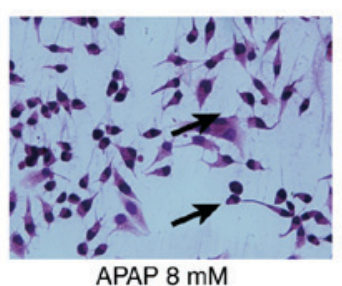

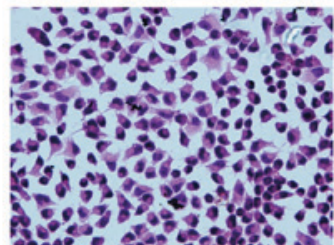
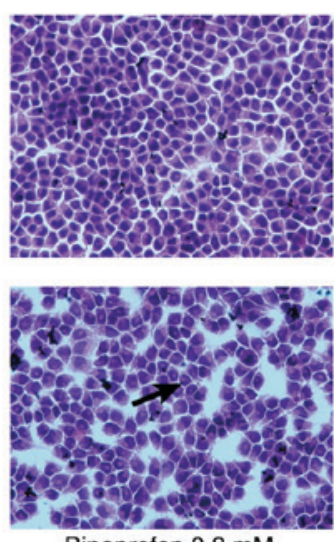

Binaprofen $0.8 \mathrm{mM}$
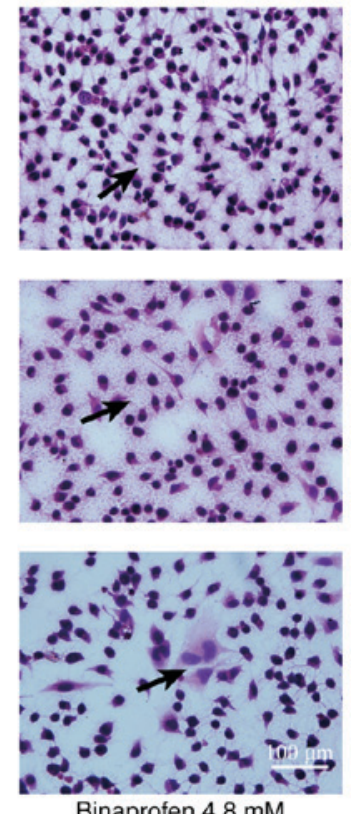

Binaprofen $4.8 \mathrm{mM}$

Figure 2. Hematoxylin and eosin staining of APAP- and binaprofen-treated liver cell lines. Treatment with $8 \mathrm{mM}$ APAP resulted in mild swelling in $1 / 5$ liver cell cultures at 6 and $12 \mathrm{~h}$, and caused mild to moderate swelling in $5 / 5$ liver cell cultures at $24 \mathrm{~h}$. Treatment with $0.8 \mathrm{mM}$ binaprofen caused no abnormalities in the five liver cell cultures at 6,12 and $24 \mathrm{~h}$, whereas $4.8 \mathrm{mM}$ binaprofen resulted in no abnormalities in liver cell cultures at $6 \mathrm{~h}$, but mild swelling in $1 / 5$ liver cell cultures at $12 \mathrm{~h}$ and mild to moderate swelling in $4 / 5$ liver cell cultures at $24 \mathrm{~h}$. The arrows indicate abnormal cells.

ASAL $>$ TBA $>$ ALT $=A S T=A L P=L D H$. Following $12 \mathrm{~h}$ of drug exposure, ASAL and TBA were identified as the most sensitive biomarkers; the sensitivity ranking was as follows: ASAL $=$ TBA $>$ ALT $=$ ALP $>$ LDH $>$ AST. Following $24 \mathrm{~h}$ of drug 
Table V. Secreted biomarker detection (U/l) in APAP- and binaprofen-treated liver cell culture supernatant.

\begin{tabular}{|c|c|c|c|c|c|c|}
\hline \multirow[b]{2}{*}{ Biomarker } & \multirow[b]{2}{*}{ Group } & \multirow[b]{2}{*}{ Concentration (mM) } & \multirow[b]{2}{*}{$\mathrm{n}$} & \multicolumn{3}{|c|}{ Time } \\
\hline & & & & $6 \mathrm{~h}$ & $12 \mathrm{~h}$ & $24 \mathrm{~h}$ \\
\hline \multirow[t]{4}{*}{ ALT } & Control & - & 5 & $3.3 \pm 1.4$ & $2.5 \pm 0.0$ & $3.3 \pm 1.4$ \\
\hline & APAP & 8 & 5 & $5.0 \pm 0.0$ & $5.0 \pm 2.5$ & $8.3 \pm 1.4^{\mathrm{a}}$ \\
\hline & Binaprofen & 0.8 & 5 & $5.8 \pm 2.9$ & $5.0 \pm 0.0$ & $4.2 \pm 1.4$ \\
\hline & Binaprofen & 4.8 & 5 & $4.2 \pm 2.9$ & $4.2 \pm 1.4$ & $7.5 \pm 2.5^{\mathrm{a}}$ \\
\hline \multirow[t]{4}{*}{ AST } & Control & - & 5 & $10.0 \pm 4.3$ & $11.7 \pm 2.9$ & $6.7 \pm 2.9$ \\
\hline & APAP & 8 & 5 & $8.3 \pm 3.8$ & $14.2 \pm 3.8$ & $20.8 \pm 11.8$ \\
\hline & Binaprofen & 0.8 & 5 & $10.0 \pm 4.3$ & $10.0 \pm 2.5$ & $14.2 \pm 2.9^{\mathrm{a}}$ \\
\hline & Binaprofen & 4.8 & 5 & $10.8 \pm 3.8$ & $11.7 \pm 1.4$ & $16.7 \pm 3.8^{\mathrm{a}}$ \\
\hline \multirow[t]{4}{*}{ ALP } & Control & - & 5 & $31.7 \pm 10.1$ & $27.5 \pm 2.5$ & $25.0 \pm 5.0$ \\
\hline & APAP & 8 & 5 & $40.8 \pm 5.2$ & $34.2 \pm 6.3$ & $35.0 \pm 4.3$ \\
\hline & Binaprofen & 0.8 & 5 & $42.5 \pm 15.2$ & $29.2 \pm 3.8$ & $33.3 \pm 1.4$ \\
\hline & Binaprofen & 4.8 & 5 & $35.0 \pm 8.7$ & $32.5 \pm 5.0$ & $33.3 \pm 3.8$ \\
\hline \multirow[t]{4}{*}{ LDH } & Control & - & 5 & $87.5 \pm 16.4$ & $88.3 \pm 51.9$ & $80.0 \pm 7.3$ \\
\hline & APAP & 8 & 5 & $76.7 \pm 6.3$ & $73.3 \pm 22.7$ & $172.5 \pm 39.7^{\mathrm{a}}$ \\
\hline & Binaprofen & 0.8 & 5 & $105.8 \pm 31.6$ & $73.3 \pm 31.2$ & $105.0 \pm 51.9^{\mathrm{a}}$ \\
\hline & Binaprofen & 4.8 & 5 & $84.0 \pm 13.8$ & $73.3 \pm 64.3$ & $191.7 \pm 53.4^{\mathrm{a}}$ \\
\hline \multirow[t]{4}{*}{ ASAL } & Control & - & 5 & $25.4 \pm 11.5$ & $27.3 \pm 2.0$ & $25.9 \pm 5.3$ \\
\hline & APAP & 8 & 5 & $32.9 \pm 3.0$ & $35.9 \pm 1.3^{\mathrm{a}}$ & $38.6 \pm 2.5^{\mathrm{a}}$ \\
\hline & Binaprofen & 0.8 & 5 & $36.6 \pm 6.1^{\mathrm{a}}$ & $41.3 \pm 6.0^{\mathrm{a}}$ & $41.8 \pm 1.3^{\mathrm{a}}$ \\
\hline & Binaprofen & 4.8 & 5 & $38.1 \pm 1.2^{\mathrm{a}}$ & $42.2 \pm 3.0^{\mathrm{a}}$ & $45.0 \pm 2.5^{\mathrm{a}}$ \\
\hline \multirow[t]{4}{*}{$\mathrm{TBA}(\mu \mathrm{M} \cdot \mathrm{L}-1)$} & Control & - & 5 & $2.4 \pm 0.2$ & $1.9 \pm 0.8$ & $2.1 \pm 0.2$ \\
\hline & APAP & 8 & 5 & $3.0 \pm 0.3^{\mathrm{a}}$ & $3.0 \pm 0.3^{\mathrm{a}}$ & $3.6 \pm 0.9^{a}$ \\
\hline & Binaprofen & 0.8 & 5 & $2.3 \pm 1.1$ & $2.9 \pm 0.2^{\mathrm{a}}$ & $3.2 \pm 0.6^{\mathrm{a}}$ \\
\hline & Binaprofen & 4.8 & 5 & $2.9 \pm 0.4^{\mathrm{a}}$ & $3.0 \pm 0.2^{\mathrm{a}}$ & $3.2 \pm 0.8^{\mathrm{a}}$ \\
\hline
\end{tabular}

Data are presented as the means \pm standard deviation. ${ }^{a} \mathrm{P}<0.05$ vs. the control group. Data were analyzed using the Kruskal-Wallis test. ALT, alanine transaminase; ALP, alkaline phosphatase; APAP, acetaminophen; ASAL, argininosuccinate lyase; AST, aspartate transaminase; LDH, lactate dehydrogenase; TBA, total bile acid.

exposure, ASAL, TBA, ALT, ALP, AST and LDH were all sensitive biomarkers and the relative sensitivities were as follows: $\mathrm{ASAL}=\mathrm{TBA}=\mathrm{AST}=\mathrm{LDH}>\mathrm{ALT}=\mathrm{ALP}$ (Table VI).

Following $24 \mathrm{~h}$ of drug exposure, the levels of the non-conventional biomarkers (TBA and ASAL), and the conventional biomarkers (ALT, AST, and LDH) were significantly altered in line with DILI.

\section{Discussion}

The most commonly recommended dose for APAP in a clinical setting is $<2 \mathrm{~g} / \mathrm{day}$. Toxicity studies have indicated that an APAP intake of $>4 \mathrm{~g}$ /day can cause liver injury (21) and that doses $>10 \mathrm{~g}$ /day may cause mortality. Most drugs are toxic at high doses; therefore, the United States Food and Drug Administration (FDA) requires drug manufacturers to indicate the lowest drug dose that is likely to cause harm. In March 2011, the FDA limited the amount of APAP in tablets or capsules to $325 \mathrm{mg}$, in order to reduce the risk of serious liver injury and allergic reactions. The daily dose allowance for APAP was not to exceed $504 \mathrm{mg} /$ day, which translates to an intake of $\sim 3.3 \mathrm{mM}$. In the present study, the $\mathrm{LC}_{50}$ of APAP in a zebrafish model of DILI was $5.2 \mathrm{mM}$, which is 1.6x higher than the current recommended clinical dose; the $\mathrm{IC}_{50}$ of APAP was $16.2 \mathrm{mM}$ in cultured liver cells, which is 4.9x higher than the current recommended clinical dose.

Binaprofen is a drug currently under investigation with a recommended clinical dose of $188 \mathrm{mg} /$ day, which is equivalent to $0.6 \mathrm{mM}$ (unpublished data from manufacturer). In the present study, it was revealed that the $\mathrm{LC}_{50}$ of binaprofen in zebrafish was $1.2 \mathrm{mM}$, which is $2 \mathrm{x}$ higher than the current recommended clinical dose; the $\mathrm{IC}_{50}$ of binaprofen in cultured liver cells was found to be $5.3 \mathrm{mM}$, which is $8.8 \mathrm{x}$ higher than the current recommended clinical dose. The results demonstrated that binaprofen is unlikely to be more toxic than APAP; however, clinical trials are required to understand binaprofen toxicity in humans.

Both APAP and binaprofen treatment led to impaired swimming and coordination in zebrafish, which are signs of cytotoxicity in these animals. However, since the main aim of this study was to investigate liver injury, histological evaluation and biomarker analysis were used as key indicators of liver health. 
Table VI. Biomarker sensitivity analysis in liver cell culture supernatants.

\begin{tabular}{lccc}
\hline & \multicolumn{3}{c}{ Time } \\
\cline { 2 - 4 } Biomarker & $6 \mathrm{~h}$ & $12 \mathrm{~h}$ & $24 \mathrm{~h}$ \\
\hline ASAL & $1.00^{\mathrm{a}}$ & $1.00^{\mathrm{a}}$ & $1.00^{\mathrm{a}}$ \\
TBA & 0.83 & $1.00^{\mathrm{a}}$ & $1.00^{\mathrm{a}}$ \\
ALT & 0.56 & 0.83 & $0.94^{\mathrm{a}}$ \\
AST & 0.56 & 0.56 & $1.00^{\mathrm{a}}$ \\
ALP & 0.56 & 0.83 & 0.94 \\
LDH & 0.56 & 0.72 & $1.00^{\mathrm{a}}$ \\
\hline
\end{tabular}

Receiver operating characteristic curve was used to determine the sensitivity of the analyzed biomarkers for the diagnosis of drug-induced liver injury. ${ }^{a}<<0.05$ vs. control group. ALT, alanine transaminase; ALP, alkaline phosphatase; ASAL, argininosuccinate lyase; AST, aspartate transaminase; LDH, lactate dehydrogenase; TBA, total bile acid.

DILI is one of the main adverse reactions caused by NSAIDs. The clinical characteristics of DILI lack specificity, and biochemical indicators may exhibit only slight abnormality or may even be normal in early stages of the disease. The clinical assessment of liver injury still largely relies on histopathological evaluation, as outlined in the Knodell and Chevallier semi-quantitative scoring systems $(22,23)$. Liver biopsy procedures are extremely traumatic for patients; therefore, sensitive biomarkers, including serum levels of enzymes, molecules or proteins offer an alternative method for monitoring DILI.

Conventional clinical biomarkers, including ALT, AST, ALP and LDH, are currently being used to monitor DILI, and are fairly accurate in predicting liver injury. ALT is considered a gold standard for monitoring liver function in the clinic. As this enzyme occurs at very high levels in the liver, particularly in the cytoplasm of liver cells, an increase in its serum levels is a good predictor of liver injury. However, serum ALT levels in patients with chronic liver fibrosis are often normal, whereas serum ALT levels of patients with burns are high, indicating that ALT levels may not always accurately predict liver injury (24). AST, another sensitive indicator of liver function (25), is an important aminotransferase enzyme that is found in cardiac muscle, liver, skeletal muscle, kidney and other tissues. In patients with chronic liver diseases, due to reduced synthesis of the enzyme, AST levels appear normal, whereas strenuous exercise can often increase serum AST levels (26). Additionally, AST levels are known to be highest in heart tissues (27); therefore, serum AST levels may not be very specific in predicting impaired liver function. ALP is a non-specific hydrolase that is widely distributed in the liver, bile duct, intestine, bone and kidney tissues (28); and increases in serum ALP levels may indicate biliary obstruction, cholestasis, gastrointestinal obstruction, or even bone and intestinal injuries. LDH is one of the most important glycolytic enzymes involved in respiration (29). It is mainly found in skeletal muscles, liver, heart, kidney and several other tissues. Although alterations in LDH levels can indicate liver injury, it is not useful in detecting problems at early stages. Studies have demonstrated that in rat models, liver damage can be detected by electron microscopy $5 \mathrm{~h}$ after injury, whereas serum LDH levels are only increased $20 \mathrm{~h}$ after injury (30). Therefore, early diagnosis of DILI with current clinical biomarkers is not very accurate or reliable. However, there are numerous non-conventional biomarkers of liver injury, whose changes in response to liver injury occur earlier and are more sensitive than conventional biomarkers.

In the present study, the ability of non-conventional biomarkers, including $\alpha$-GST, Arg-I, ASAL, TBA, PA, ICD, SDH and OCT, to predict DILI was investigated. ASAL has an important role in the ornithine cycle and is mainly found in the liver (31); serum ASAL levels are significantly increased in patients with hepatitis. Although this enzyme is also found in kidneys, serum ASAL does not increase in patients with kidney disease; therefore, ASAL may specifically predict liver injury (32). Arg-I is mainly found in the nuclei of liver cells, although it is present at low amounts in the kidney, heart, spleen, brain and muscle tissues $(33,34)$. In acute and chronic liver injury, serum Arg-I levels have been reported to increase at an earlier time point compared with serum ALT and AST levels, particularly in injuries caused by liver transplantation. $\alpha$-GST is a low molecular weight enzyme with a short half-life that is mainly found in the liver, accounting for $\sim 5 \%$ of soluble protein in liver cells $(35,36)$. A previous study suggested that $\alpha$-GST can act as a biomarker for liver injury in patients infected with Schistosomiasis mansoni (37). TBA is mainly found in liver cells, with only very low levels detected in the serum $(38,39)$ and is indicative of liver function, including protein synthesis, metabolism and secretion. Liver injuries can cause a significant increase in serum TBA levels; therefore, it is considered a sensitive biomarker for predicting liver injury. Serum TBA levels are particularly useful for diagnosing acute and chronic hepatitis, liver fibrosis and cirrhosis; studies have revealed that increased serum TBA levels are detected in $97.4 \%$ of patients with acute hepatitis, in $84.3 \%$ of patients with chronic hepatitis and in $100 \%$ of patients with cirrhosis (40). PA is a transport protein that is synthesized by liver cells and alterations in serum PA levels can be rapidly detected once its synthesis is impaired $(41,42)$. Serum PA levels have been reported to change significantly in patients with chronic hepatitis and liver cirrhosis after treatment (43). There are two types of ICD in the human body, one that utilizes $\mathrm{NAD}^{+}$and another that utilizes $\mathrm{NADP}^{+}(44,45)$. The ICD, which utilizes $\mathrm{NADP}^{+}$is present in large amounts in the liver, cardiac/skeletal muscle and kidney tissues, and alterations in its serum levels have been reported to be both sensitive and specific to injuries of hepatic parenchymal cells. SDH is mainly found in the liver, though it is also present in low levels in kidney, brain, heart and spleen tissues $(46,47)$. Therefore, serum SDH levels may serve as a sensitive and specific biomarker for predicting liver injury. OCT is mainly found in liver mitochondria where it is the key enzyme that metabolizes ammonia into urea in the ornithine cycle (48). It is a liver-specific enzyme and only very low amounts are found in other tissues; therefore, it may function as a specific biomarker for liver disease. All of the non-conventional biomarkers described here may reflect different characteristics of liver injury due to their varying functions and distributions.

The ROC curve is a graphical tool used to test the accuracy of diagnostic tests. It evaluates the accuracy and diagnostic value 
of a diagnostic test in an objective and comprehensive manner, by calculating its sensitivity and specificity in distinguishing between patients with disease regardless of disease incidence.

ROC curve and area under the curve (AUC) are used to assess the accuracy of a diagnostic test, and screen for the best diagnostic test for a particular disease. If the AUC of an ROC curve is $\leq 0.5$ this indicates that a test has no diagnostic value, whereas an AUC between 0.5 and 0.7 indicates low diagnostic value, an AUC of 0.7-0.9 indicates medium diagnostic value and an AUC >0.9 indicates high diagnostic value.

Overall, the results of the present study demonstrated that ASAL and TBA levels are increased during the early stages of DILI, and that this increase occurs earlier compared with the conventional biomarker ALT. These two enzymes were also more accurate in predicting liver injury compared with ALT in both the in vivo zebrafish and in vitro liver cell DILI model. According to these findings, ASAL and TBA may be the most sensitive biomarkers in predicting DILI caused by binaprofen. However, there are limitations to using model systems and further research is required to confirm the results. It is recommended that ASAL and TBA are tested as biomarkers in future clinical trials to obtain more accurate conclusions. TBA can be detected using a biochemical analyzer, which makes it an easy biomarker to measure in a clinical setting. TBA, ASAL, ALT and AST could also be detected in combination to predict DILI caused by binaprofen, as this may improve the efficiency and accuracy of early diagnosis.

In conclusion, the NSAID binaprofen induced similar liver toxicity in vitro and in vivo compared with APAP. The non-conventional biomarkers TBA and ASAL were identified as the most sensitive early biomarkers for predicting DILI caused by binaprofen and may serve as novel DILI biomarkers in the future.

\section{Acknowledgements}

Not applicable.

\section{Funding}

The present study was financially supported by the Foundation of Ministry of Education and Science of Guangdong Province, P.R. China (grant no. 2012B090600020), the Ministry of Science and Technology of Guangzhou City, P.R. China (grant no. 2011070), the Science and Technology Plan Projects of Guangdong Province, P.R. China (grant no. 2016A010119136) and the High-Level Leading Talent Introduction Program of Guangdong Academic of Sciences, P.R. China (grant no. 2016GDASRC-0104).

\section{Availability of data and materials}

All data generated or analyzed during this study are included in this published article.

\section{Authors' contributions}

QG, JG, RJ, WY and CL conceived and designed the study. QG, $\mathrm{GC}, \mathrm{JG}, \mathrm{ZH}$ and $\mathrm{BX}$ performed the experiments, and completed the acquisition of data, QG, JG, WY and CL completed the analysis and interpretation of data for the study. QG and JG wrote the paper. All authors read and approved the manuscript.

\section{Ethics approval and consent to participate}

The present study was approved by the Institutional Animal Care and Use Committee of Guangzhou Pharmaceutical Research Institute (protocol no. 2012005-01) and were conducted in accordance with international guidelines for the care and use of laboratory animals.

\section{Patient consent for publication}

Not applicable.

\section{Competing interests}

The authors declare that they have no competing interests.

\section{References}

1. Koller T, Galambosova M, Filakovska S, Kubincova M, Hlavaty T, Toth J, Krajcovicova A and Payer J: Drug-induced liver injury in inflammatory bowel disease: 1-year prospective observational study. World J Gastroenterol 23: 4102-4111, 2017.

2. Kotsampasakou E, Montanari F and Ecker GF: Predicting drug-induced liver injury: The importance of data curation. Toxicology 389: 139-145, 2017.

3. McEuen K, Borlak J, Tong W and Chen M: Associations of drug lipophilicity and extent of metabolism with drug-induced liver injury. Int J Mol Sci 18: E1335, 2017.

4. Juthani VV, Clearfield E and Chuck RS: Non-steroidal anti-inflammatory drugs versus corticosteroids for controlling inflammation after uncomplicated cataract surgery. Cochrane Database Syst Rev 7: CD010516, 2017.

5. Mishra A, Amalakara J, Avula H and Reddy K: Effect of diclofenac mouthwash on postoperative pain after periodontal surgery. J Clin Diagn Res 11: ZC24-ZC26, 2017.

6. Zamir Q and Nadeem A: Non-steroidal anti-inflammatory drugs vs. Paracetamol: Drug availability, patients' preference and knowledge of toxicity. J Ayub Med Coll Abbottabad 28: 746-749, 2016.

7. Savjani JK, Mulamkattil S, Variya B and Patel S: Molecular docking, synthesis and biological screening of mefenamic acid derivatives as anti-inflammatory agents. Eur J Pharmacol 801: 28-34, 2017.

8. Shin JY, Song I, Lee JH, Yoon JL, Kwon JS and Park BJ: Differential risk of peptic ulcer among users of antidepressants combined with nonsteroidal anti-inflammatory drugs. J Clin Psychopharmacol 37: 239-245, 2017.

9. Rostom A, Goldkind L and Laine L: Nonsteroidal anti-inflammatory drugs and hepatic toxicity: A systematic review of randomized controlled trials in arthritis patients. Clin Gastroenterol Hepatol 3: 489-498, 2005.

10. Rathi C, Pipaliya N, Patel R, Ingle M, Phadke A and Sawant P: Drug induced liver injury at a tertiary hospital in India: Etiology, clinical features and predictors of mortality. Ann Hepatol 16: 442-450, 2017.

11. Soleimanpour M, Imani F, Safari S, Sanaie S, Soleimanpour H, Ameli $H$ and Alavian SM: The role of non-steroidal anti-inflammatory drugs (NSAIDs) in the treatment of patients with hepatic disease: A review article. Anesth Pain Med 6: e37822, 2016

12. Bunchorntavakul $\mathrm{C}$ and Reddy KR: Acetaminophen (APAP or N-Acetyl-p-Aminophenol) and acute liver failure. Clin Liver Dis 22: 325-346, 2018.

13. Guo Q, Chen G, Zhou Q and Jin R: Comparison of hepatotoxicity and toxic mechanisms of matrine and oxymatrine using in vivo and in vitro models. Chinese J Comparative Med 28: 44-50, 2018 (In Chinese).

14. Xiao Y, Lin M, Jiang X, Ye J, Guo T, Shi Y and Bian X: The recent advance on liver cancer stem cells: Biomarkers, separation, and therapy. Anal Cell Pathol (Amst) 2017: 5108653, 2017. 
15. Wang W, Ou HY, Xiao BQ, Huang YJ, Yang W and Wang QS The study of abirritation of a first type of new drug, felbinac trometamol injection. Chin J Med Guide 11: 1327-1332, 2009.

16. Wang $\mathrm{W}, \mathrm{Ou} \mathrm{H}$ and Liang $\mathrm{H}$ : Preliminary pharmacodynamics and safety studies of a first type of new drug, felbinac trometamol injection. Chin J Ethnomedicine Ethnopharmacy 12: 3-4, 2009 (In Chinese).

17. Zhang C, Cui X, Yang Y, Gao F, Sun Y, Gu J, Fawcett JP, Yang W and Wang W: Pharmacokinetics of felbinac after intravenous administration of felbinac trometamol in rats. Xenobiotica 41 340-348, 2011

18. AVMA Guidelines for the Euthanasia of Animals: 2013 Edition. Version 2013.0.1 American Veterinary Medical Association, Schaumburg, IL, 2013.

19. Riera TV, Wigle TJ and Copeland RA: Characterization of inhibitor binding through multiple inhibitor analysis: A novel local fitting method. Methods Mol Biol 1439: 33-45, 2016.

20. Nagendra S, Vanlalhmuaka, Verma S, Tuteja U and Thavachelvam K: Recombinant expression of bacillus anthracis lethal toxin components of indian isolate in escherichia coli and determination of its acute toxicity level in mouse model. Toxicon 108: 108-114, 2015.

21. Liao CC, Day YJ, Lee HC, Liou JT, Chou AH and Liu FC: ERK signaling pathway plays a key role in baicalin protection against acetaminophen-induced liver injury. Am J Chin Med 45: 105-121, 2017.

22. Knodell RG, Ishak KG, Black WC, Chen TS, Craig R, Kaplowitz N, Kiernan TW and Wollman J: Formulation and application of a numerical scoring system for assessing histological activity in asymptomatic chronic active hepatitis. Hepatology 1: 431-435, 1981

23. Chevallier M, Guerret S, Chossegros P, Gerard F and Grimaud JA A histological semiqunatitative scoring system for evaluation of hepatic fibrosis in needle liver biopsy specimens: Comparison with morphometric studies. Hepatology 20: 349-355, 1994.

24. Kumar M, Sarin SK, Hissar S, Pande C, Sakhuja P, Sharma BC, Chauhan R and Bose S: Virologic and histologic features of chronic hepatitis B virus-infected asymptomatic patients with persistently normal ALT. Gastroenterology 134: 1376-1384, 2008.

25. Malinoski FJ: Strenuous exercise simulating hepatic injury during vaccine trials. Vaccine 10: 39-42, 1992

26. Smith JE, Garbutt G, Lopes P and Tunstall Pedoe D: Effects of prolonged strenuous exercise (marathon running) on biochemical and haematological markers used in the investigation of patients in the emergency department. Br J Sports Med 38: 292-294, 2004

27. Shen J, Zhang J, Wen J, Ming Q, Zhang J and Xu Y: Correlation of serum alanine aminotransferase and aspartate aminotransferase with coronary heart disease. Int J Clin Exp Med 8: 4399-4404, 2015

28. Halkes S, van den Berg A, Hoekstra M, du Pont J and Kreis R: Transaminase and alkaline phosphatase activity in the serum of burn patients treated with highly purified tannic acid. Burns 28 : 449-453, 2002

29. Moss DW and Henderson AR: Enzymes. In: Tietz Fundamentals of Clinical Chemistry. Burtis CA and Ashwood ER (eds). 5th edition. WB Saunders, Philadelphia, PA, pp 735-896, 1999.

30. Hu GH and Lü XS: Effect of normothermic liver ischemic preconditioning on the expression of apoptosis-regulating genes C-jun and Bcl-XL in rats. World J Gastroenterol 11: 2579-2582, 2005.

31. Ashamiss F, Wierzbicki Z, Chrzanowska A, Scibior D, Pacholczyk M, Kosieradzki M, Lagiewska B, Porembska Z and Rowiński W: Clinical significance of arginase after liver transplantation. Ann Transplant 9: 58-60, 2004

32. Chen GF and Baylis C: In vivo renal arginine release is impaired throughout development of chronic kidney disease. Am J Physiol Renal Physiol 298: F95-F102, 2010.
33. Stéphenne X, Najimi M, Sibille C, Nassogne MC, Smets F and Sokal EM: Sustained engraftment and tissue enzyme activity after liver cell transplantation for argininosuccinate lyase deficiency. Gastroenterology 130: 1317-1323, 2006.

34. Murayama H, Ikemoto M, Fukuda $Y$, Tsunekawa $S$ and Nagata $A$ : Advantage of serum type-I arginase and ornithine carbamoyltransferase in the evaluation of acute and chronic liver damage induced by thioacetamide in rats. Clin Chim Acta 375: 63-68, 2007.

35. Ray DC, Robbins AG, Howie AF, Beckett GJ and Drummond GB: Effect of spinal anaesthesia on plasma concentrations of glutathione S-transferase. Br J Anaesth 88: 285-287, 2002.

36. Ahmed AM, Abdel-Tawab AH and Morsy AT: Alpha-Glutathione S-transferase and serum aminotransferases in schistosomiasis mansoni patients with or without hepatitis C virus. J Egypt Soc Parasitol 38: 561-572, 2008.

37. Ouaissi A, Ouaissi M and Sereno D: Glutathione S-transferases and related proteins from pathogenic human parasites behave as immunomodulatory factors. Immunol Lett 81: 159-164, 2002

38. Yang X, Lei J, Zhang Y, Tang X, Zheng Y and Chen J: The diagnostic value and limitation of total serum bile acid determined enzymatically. Zhonghua Nei Ke Za Zhi 40: 16-18, 2001 (In Chinese).

39. Negoro S, Tanaka A and Takikawa H: Urinary bile acid sulfate levels in patients with hepatitis $\mathrm{C}$ virus related chronic liver diseases. Hepatol Res 39: 760-765, 2009.

40. Neale G, Lewis B, Weaver V and Panveliwalla D: Serum total bile acids in liver diseases. Gut 12: 145-152, 1971.

41. Caccialanza R, Palladini G, Klersy C, Cereda E, Bonardi C, Quarleri L, Vadacca G, Albertini R and Merlini G: Serum prealbumin: An independent marker of short-term energy intake in the presence of multiple-organ disease involvement. Nutrition 29: 580-582, 2013

42. Aliyazicioglu Y, Dagdemir A, Dilber C and Albayrak D: Serum prealbumin levels in hepatotoxicity of chemotherapy in children with cancer. Bratisl Lek Listy 113: 368-371, 2012.

43. Saito M, Seo Y, Yano Y, Miki A, Yoshida M and Azuma T: Short-term reductions in non-protein respiratory quotient and prealbumin can be associated with the long-term deterioration of liver function after transcatheter arterial chemoembolization in patients with hepatocellular carcinoma. J Gastroenterol 47: 704-714, 2012.

44. Chung YH, Kim JA, Song BC, Song IH, Koh MS, Lee HC, Yu E, Lee YS and Suh DJ: Isocitrate dehydrogenase as a marker of centrilobular hepatic necrosis in the experimental model of rats. J Gastroenterol Hepatol 16: 328-332, 2001.

45. Racine-Samson L, Scoazec JY, D'Errico A, Fiorentino M, Christa L, Moreau A, Roda C, Grigioni WF and Feldman G: The metabolic organization of the adult human liver: A comparative tudy of normal, fibrotic, and cirrhotic liver tissue. Hepatology 24: 104-113, 1996.

46. Pathiratne A, Pathiratne KA and De Seram PK: Assessment of biological effects of pollutants in a hyper eutrophic tropical water body, Lake Beira, Sri Lanka using multiple biomarker responses of resident fish, Nile tilapia (Oreochromis niloticus). Ecotoxicology 19: 1019-1026, 2010.

47. Harrill AH, Roach J, Fier I, Eaddy JS, Kurtz CL, Antoine DJ, Spencer DM, Kishimoto TK, Pisetsky DS, Park BK and Watkins PB: The effects of heparins on the liver: Application of mechanistic serum biomarkers in a randomized study in healthy volunteers. Clin Pharmacol Ther 92: 214-220, 2012.

48. Murayama H, Ikemoto M and Hamaoki M: Ornithine carbamyltransferase is a sensitive marker for alcohol-induced liver injury. Clin Chim Acta 401: 100-104, 2009. 